\title{
ANALISIS SEJARAH DAGANG MUHAMMAD PRA KERASULAN
}

\author{
Oleh : Syarifuddin
}

\begin{abstract}
ABSTRAK
Nabi Muhammad adalah sosok pribadi yang paripurna dan tak habis-habisnya digali dan didiskusikan oleh umat manusia. Seluruh dimensi kehidupan dikupas dan dikaji secara mendalam baik sejarawan muslim maupun tokoh-tokoh pemikir non muslim di seluruh entero dunia. Namun dimensi ketokohan dan kepopulerannya dalam dunia usahan dan bisnis sukses dalam legenda cerita, tapi kajian tulisan sangat memperihatinkan. Realita itu, mendorong penulis menelusuri lembaran-lembaran sejarah tentang karir dagang Muhammad dalam merubah peradaban kota Makkah dan Madinah serta menjadikan daera ini jalur perdagangan Internasional. Dobrakan ekonomi yang di kembangkan terpengaruh oleh kondisi lingkungan bngsa Arab yang telah terkontaminasi dengan ekonomi Romawi dan Persi.
\end{abstract}

Kata Kunci : Sejarah, Dagang

\section{A. Pendahuluan}

Pergolakan perdagangan dunia tak mungin lagidihindari suka atau tidak suka, siap atau tidak siap kita akan terlibat langsung dan diharapkan berperan aktif dalam proses yang begitu cepat dengan segala dampaknya. Mencermati persaingan global di bidang ekonomi, para ekonom mencoba mencari jawaban akan fenomena kesuksessan berbagai bangsa di dunia. Para ekonom mencoba dengan cara menggali berbagai nilai dan norma yang berakar serta melekat secara umum pada bangsa itu sendiri.

Kaum muslimin di dunia, mencoba menggalo dan memahami isi alquran melalui seorang insane yang ummi. Namun mampu mendobrak kultur tradisi bangsa arab menjadi bangsa yang beradab.

Sosok Muhammad SAW adalah profile tokoh fantastis yang telah menyedot sekian banyak perhatian para ilmuan, kususnya sejarawan seantero jagat. Hal ini di samping beliau adalah nabi utusan Allah SWT, juga adalah tokoh yang sangat monumental menancapkan perannya dalam transformasi peradaban dan sejarah manusia. Membuka tirani persial, 
mengahncurkan kultur perbudakan, mandorong semangat pembaharuan dan membuka sayap tali persaudaraan yang berlandaskan nilai-nilai kemanusiaan sejati dan ketuhanan.

Sejarah tak mungkin dimengerti sebagai kronologis peristiwa tanpa factor. Fakta peristiwa menunjukan bahwa bangkutnya agama, sekte atau kultus modern lain dalam berbagai tingkatan dan area selalu bergerak dari satu sosok pribadi tokohnya. Hampir semua sejarawan, baik muslim maupun barat mengakui nabi Muhammad saw adalah sosok pribadi yang kompleks. Beliau adalah Nabi dan Rasul Allah swt, panglima perang yang handal dan ahli dalam menyusun strategi, sekaligus sebagai sosok kepala Negara yang bertindaksebagai negarawan, politisi, dan yang tak kalah menabjukan maupun menjadikan timur tengah sebagai jalur perdagangan Internasional dikala itu. ${ }^{1}$

Lain dari figure utusan Allah swt, yang lain, Muhammad saw dikenal oleh kaumnya tidak terbatas pada ajaran spiritualnya saja melainkan juga seluruh aspek kehidupoan sejak masa kelahirannya sampai dengan wafatnya. Ketokohan Nabi Muhammad saw, dalam literatur sejarah tidak hanya diakui oleh kaum muslimin tetapi juga diperkuat dan dikagumi para sejarawan dunia. Tidak terdapat catatan historis yang begitu kompleks tentang seorang Nabi dan rasul, kecuali Biografi Muhammad. Karena kompleksnya itulah, maka berbagai penafsiran muncul baik golongan pro maupun kontra.

Pengkajian tentang ketokohan dan posisi Muhammad saw, entah sebagai politikus, negarawan, filsuf, pedagang ataupun figure seorang nabi, namun kata-kata tersebut yang tersandang pada dirinya tidak terjadi pertentangan dan tidak mengurangi eksistensi sebagai tokoh spiritual dan peletak dasar ajaran Islam.

Sisi kefiguran Muhammad saw, dari sudut pandang ilmu ekonomi ajaran dan ketauladan yang ditinggalkan ternyata jauh mendahului jamannya sehingga berbagai prinsip moral atau etika bisnis yang diwariskan semakin terasa urgnsinya jika direlevansikan dengan kondisi dan cita-cita masyarakat sekarang yaitu menuju masyarakat yang adil dan makmur.

Di era transformaasi dan globalisasi ekonomi dunia yang membutuhkan efisiensi, transparansi, persaingan yang sehat, kredibilitas, memelihara relasi melalui layanan yang manusiawi, kesemua ini dapat dengan mudah kita temukan dalam etika dan perilaku bisnis Muhammad saw, maka kita akan mendapatkan sedikit reverensi yang menyorot karir Muhammad saw sebagai saudagar dan usahawan. Dengan realita inilah penulis mencoba

\footnotetext{
${ }^{1}$ W. Monhomeny Watt, Muhammad Prophed and Statement, Oxfort; University Pers, 1961.
} 
membuka tabir karir dagang seorang tokoh monumental dunia dan akhirat. Dengan persoalan bagaimana jenjang karir Muhammad saw dalam dunia perdagangan?

\section{B. Pembahasan.}

\section{a. Keadaan Bangsa Arab Pra Kerasulan Muhammad saw.}

Tidak terdapat informasi yang cukup akurat tentng sejarah bangsa Arab sebelum datangnya islam. Hal ini paling tidak disebabkan oleh dua hal yaitu mereka belum memiliki kekuatan politik karena pada umumnya mereka hidup (nomadan), para ahli geografi pada masa dulu mencatat bahwa semenanjung Arab yang terletak disebelah barat daya Asia dan dikelilingi oleh laut merah, Samudera Hindia, serta teluk terbagi atas:

1. Arab Petriks, daerah yang terletak disebelah Barat daya gurun Syiria, dengan Petra sebagai Ibu kota.

2. Arab Deserta, nama yang didasarkan pada masa gurun Syiria, karena Syiria, dengan Petra sebagai ibu kota.

3. Arab Feliks, daera Yaman, suatu daera yang dikenal dengan nama Saba yang telah mempunyai peradaban maju pada masanya. ${ }^{2}$

Sementara itu ahli geogrefi Arab membagi wilayah dapam lima bagian berdasarkan keadaan tanahnya:

1. Tihamah, dataran rendah yang terbentang lurus disepanjang pantai laut Merah, dari Yambu sampai Najaran Yaman.

2. Hijaz, suatu daerah sebelah utara Yaman dan sebelah timur Tihamah, daerah ini adalah lembah yang subur sekaligus menjadi pemisah antara Tihamah dan Najd.

3. Najd, daerah yang membentang antara yaman disebelah utara, dan antara al Rud dengan perbatasan Irak di sebelah timur, dikatakan Najd karena ketinggian tanahnya.

4. Yaman, Membentang dari Najd sampai laut Hindia disebelah selatan sampai laut Merah disebelah Barat. Daerah ini, menghubungkan hadramaut, Shiber dengan Oman disebelah timur.

2 Hasan Ibrahi Hasan, diterjemahkan oleh Jahdan Human, Sejarah dan Kebudayaan Islam, (cet. I Yogyakarta; Kota Kembang 989),h. 15 
5. Al Rud, terdiri dari Yaman dan Bahrain disebut demikian karena terletak melintang Yaman, Najd dan Irak. ${ }^{3}$

Walaupun kelihatan analisis geogrefi cenderung berbeda, namun dapat ditarik kompromi bahwa keduanya sama-sama melihat bahwa daerah Yaman adalah daerah yang subur dan telah memiliki peradaban maju termasuk Hijaz yang berada disebelah Utara yaman. Dalam analisis sosiologis hostoris, bangsa Arab dibagi dua golongan besar, yaitu Qathar dan Adnan. Qathar adalah mereka yang semula bertempat tinggal di Yaman, sedangkan Adnan adalah mereka yang berasal dari keturunan Ismail bin Ibrahim yang mayoritas menempati pusat semenanjung Arab dan Hijaz. Pembaharauan kemudian terjadi ketika penduduk yaman setelah berimigrasi ke Utara akibat terjadinya peristiwa robohnya bendungan raksasa Magrib ibu kota Saba sekitar tahun 120 SM, dan menyebabkan berdirinya kerajaan Hira dan Ghassan. ${ }^{4}$

Para Imigran dari Yaman dipimpin oleh Bani Qilan dan menempati Yatsrib (Madinah Sekarang), yang merupakan cikal bakal bani Aus dan Khazraj yang senantiasa bertikai hingga datangnya Muhammad saw ke Yastrib. Hal ini kemudian dalam analisis penulis menjadi salah satu sebab diterimanya Muhammad dengan damai dan berkembangnya Islam begitu cepat.

Sukui Qurauisy yang merupakan suku asal Muhammad memiliki kehormatan untuk menjadi penjaga Ka'bah dan melaksanakan kewenangan keagamaan paling tingi dibandingkan dengan suku-suku yang lain. Dalam srtuktur kesukuan Arab suku Quraisy masih marga Kinanah yang sebagaimana menetap di lembah Makkah setelah menyingkirkan suku Khuzaah di Arab ke lima ${ }^{5}$ dibawah pimpinan Mudzaz, kemudian ia kembali merebut posisi kunci di Makkah dengan dukungan penuh Klan Quraisy.

Berawal dari sini, Qusay mempunyai empat putra yakni Abu Dar, Abdul Manaf, Abd Uzza, Abd Qusay, sepeninggalan Qusay pujuk pimpinan diserahkan kepada Abu Dar, namun selain beberapa puluh tahun kemudian putra Abd Manaf yakni Abd Saws, Nafwal Hasyim, Abdul Muthalib dan Hasan bermaksud mengambil kekuasaan. Sehingga terjadilah sengketa antara keluarga Abu Dah dan Abdul Manaf yang berakhir dengan adanya kesepahaman untuk

\footnotetext{
${ }^{3}$ Ibid.h. 16

${ }^{4}$ Ibid, h. 17

${ }^{5}$ Ibid, Fuad Hasan, h. 44
} 
melakukan kompromi, pembagian job, dimana keluarga Abd. Manaf memegang kendali logistik dan keluarga Abu Dar menangani urusan pertemuan tahunan.

Satu hal yang menarik bahwa kondisi geografis lembah Makkah yang tandus, dan eksistensi rumah K'bah yang menjaddi pusat peribadatan dan tempat kunjungan ziarah berbagai bangsa diberbagai bangsa di dunia, sehingga menimbulkan efek positif bagi posisi masyarakat dimana mereka menjadi pedagang-pedagang yang tnagguh dan ulet. Terlebih ketika terjadi suatu kanca peperangan yang begitu dahsyat antara Bizantium (Romawi) dan persiah yang menyebabkan macetnya lalulintas perdagangan laut yang melintasi teluk Persi. Perdagangan kemudian berubah jalur dari laut menjadi darat yang melintas Yaman ke Siria, atau sebaliknya yang menjadikan posisi Makkah sebagai rute dan sekaligus tempat transit perdagangan yang sangat ramai. ${ }^{6}$

\section{b. Perdagangan Masa Arab Kuno}

Kondisi wilayah bangsa Arab yang kering, tandus, padang pasir, pegunungan penuh dengan bebatuan yang terkenal dalam sejarah. Situasi seperti ini memberikan spiritual yang kuat untuk melangsungkan kehidupan dengan jalan yang berdagang. Kondisi sebagian tanah diwilayah Hijaz, kususnya disekitar Makkah memang seperti itu. Hal yang demikian itu digambarkan dlam alquran yang terungkap dalam doa Nabi Ibrahim.;

Ya Tuhan Kami, sesungguhnyan aku telah menempatkan keturunanku dilembah yang tandus dekat Rumah SuciMu (Ka’Bah)” (QS. 14 ; 37).

Denag demikian, penganut agama ini secara ini menempuh dan memposisikan diri dalam bidang perdagangan. Kaum Quraisy, berdasarkan kepemimpinan mereka sebagai kaum penjaga Ka'bah, mempunyai peluang yang besar dan kemudahan dalam bidang perdagangan,. Kehidupan politik bangsa arab yang sangat tidak pasti. Kehidupan kesukuan yang mandiri merupakan cara hidup yang biasa. Tidak terdapatnya pemegang kekuasaan sentral mendorong setiap suku untuk bertanggung jawab menjaga keselamatannya sendiri. Hal yang demikian ini, tidak ada jaminan akan terbentuknya suatu kedamaian dan keamanan wilayah itu. Walaupun demikian, kaum

\footnotetext{
${ }^{6}$ Hasan Ibrahim Hasan, Op, Cit h. 19, Bandingkan dengan Fuad Hasan, Op.Cit, h. 45
} 
Quraisy dengan posisinya sebagia penjaga Ka'bah sangat luas dan amakn untuk melakukan perjalanan dagang diseluruh kawasan.

Kaum Quraisy merupaka suku arab yang paling berpengaruh dan terhormat, merupakan suku Nabi Muhammad berasal. Atas eksistensinya sebagia penjaga Ka'bah tempat suci mereka paling tidak mendapatkan keuntungan yaitu;

1. Pengaruh kuat atas suku-suku lainnya

2. Posisi sentral yang memberikan kemudahan dalam perdagangan dan membangun relasi. Hal ini selain memberikan keuntungan sendiri juga kehormatan pada mereka.

3. Wilayah bangsa Arab berdasarkan adat kebiasaan merupakan bangsa yang bebas dari peperangan dan permusuhan individu yang menyebabkan posisi mereka terjamin, tidak ada rasa takut dan terhindar dari marabahaya. ${ }^{7}$

Disaat terjadi peperangan antar suku yang menimbulkan rasa saling bermusuhan dan perasaan tidak aman, sepenuhnya mereka tetap menikmati keamanan dan kehormatan wibawah, baik dalam maupun luar negeri. Mereka mendapatkan kehormatan sebagai pemimpin bangas Arab ke wilayah mana pun mereka pergi berdagang. Status ini juga memungkinkan mendapatkan keuntungan dalam melakukan perdagangan politik dari Negara-negara tetangga.

Dalam menjalankan usaha dagang mereka mengatur strategi perdagangan dengan cara mengutus kafilah dagang ke Utara (Siria, Iran, dan Iraak) pada musim panas, dan daerah selatan (Yaman, dan Ethiopia) pada musim dingin tanpa memiliki rasa takut akan bahaya. Dalam mengembangkan usaha dagangnya membentuk aneka jenis organisasi usaha kerja serta menambah wawasan dagan akibat terjadinya kontak dengan Negara lain. Usaha kekayaan dan kemakmuran dan makkah menjadiu pusat perdagangan yang paling penting di semenanjung Arab. Pada msa ini perdagangan telah mencapai kejayaan dan Nabi mendapatkan dampak yang sangat besar darinya ketika memulai karirnya sebagai seorang pedagang.

\footnotetext{
${ }^{7}$ Fazrul rahman, Ibid, h. 3
} 


\section{Meretas Karir Dagang Muhammad}

Dibalik lembaran sejarah terungkap silsilah keturunan Muhammad sebagai suku yang memegang posisi penting di kota Makkah. Muhammad adalah hasil perkawinan antara Abdullah dengan Aminah. Sesuai adab kebiasaan Arabbilah perkawinan dilangsungkan di rumah putri. Maka pengantin akan pindah kerunmah suaminya yang baru. Belum menikmati lamanya sebagai pengantin baru Abdullah punmeninggalkan isterinya dalam misi perdagangan ke Suria, sedang Amina dalamkeadaan hamil. Dalam perjalanan dagang Abdullah meninggal dunia. Selang beberapa bulan setelah meninggalnya Muhammad dilahirkan ${ }^{8}$, setelah dilahirkan ia disusui oleh Halimah bint Abi Dhua'ib di tinggal di Sahara di bawah asuhan Syaima'. Ia disusukan selama dua tahun. Kemudian di ambil oleh ibu kandungnya. Namub dalam asuhan Halman Muhammad dibelah dadanya. Selama 15 tahun berada dalam asuhan Halimah kemudian dikembalikan kepada Ibunya namun belum berapa lama bersama ibunyaia ditinggal dalam keadaan yatim piatu. Kemudian asuhan berpindah ke kakeknya Abdul Muthalib. Namun beberapa tahun saja bersama kakeknya meninggal kemudian ia tinggal bersama pamannya Abu Thalib yang berprofesi sebagai pedagang sebagaimana kebanyakan pemimpin Quraisy lainnya. Kondisi sepert ini didukung oleh wilaya yang mana berdagang mrupakan pendapatan utama penduduk Mekah.

Muhammad memulai karir perjalanan dagangnya ketika ia berusia 12 tahun ketika pertama kali melakukan perjalanan dagang ke Syiria bersama pamannya. Kebetulan Abu Thalib Ibn Abdul Muthalib telah merencanakan melakukan perjalanan bersama kelompok pedagang dalam ekspedisi dagang ke Syiria. Ketika semua perbekalan telah siap dan kelompok terebut berkumpul untuk meninggalkan Makkah, Nabi yang waktu itu masih seorang pemudah kecil, merangkul pamannya dan memperlihatklan kasih sayangnya yang sangat besar sehingga Abu Thalib marasa iba. Beliau berkata "aku akan membawahnya bersamaku, dan kami tidak akan pernah berpisah" selanjutnya, Muhammad diajak dalam perjalanan.

Ketika perjalanan memasuki kota Busra (Syiria) ada seorang pendeta bernama Bahira yang tinggal di sebuah biara. Pendeta ini sangat luas pengetahuannya mengenai kisah-kisah di kalangan orang Kristen sudah sejak lama biara tersebut selalu ditempati oleh seorang pendeta. Di

\footnotetext{
${ }^{8}$ Beberapa ahli berlainan pendapat tentang hari kelahiran Muhammad, Ibn Abbas mengatakan Muhammad dilahirkan pada tahun gaja tepat, disisi lain mengatakan 15 tahun sebelum tahun gaja, sedangkan pendapat lain ia dilahirkan beberapa hari atau beberapa bulan sesudah tahun gajah. Para ahli berbeda berpendapat bulan kelahirannya sebagian besar mengatakan bulan rabiul awwal, ada yang berkata bulan Muharram , bulan safar, dan bulan rajab. Caussin de Perceval dalam Essai sur I'Histori des Arabe menyatakan Muhammad dilahirkan bulan Agustus 570, yakni tahun Gajah. Dalam Buku Muhammad Husain Haekal,
} 
biara itu, terdapat sebuah manuskrip kuno yang tersimpan sebagai kepercayaan yang telah diwariskan dari satu generasi ke generasi berikutnya. Ketika rombongan Abu Thalib tibah di kota Busrah dan melakukan istirahat (membuat Kemah) di dekat Biara. Pendeta itu keluar dan mengundang rombongan untuk menghadiri jamuan yang sudah disiapkan bagi mereka. Namun mereka belum pernah diundang makan malam bersama pendeta tersebut selama mereka mengadakan perjalanan dagang.

Bahira, penjaga biara telah mengatur sebuah pesta besar yang diperuntuhkan bagi rombongan Abu thalib. Sebab dari dalam biara Bahira melihat rombongan yang singgah bersama seorang anak muda yang dilindungi oleh sekumpulan awan putih, mengesampingkan yang lainnya. Ia juga memperhatikan cabang-cabang pohon tempat anak muda itu beristirahat semuanya merunduk sehingga anak muda itu terlindungi. Ketika melihat yang demikian itu Bahira keluar dari biaranya dan berkata "saya telah menyediakan untuk kalian wahai kaum Quraisy, dan saya ingin kalau semua dating, baik yang besar maupun yang kecil, termasuk para budak ${ }^{9}$.

Perjalanan dagang Nabi Muhammad bersama Pamannya, ia mendapatkan kesan dan pengaruh dalam jiwanya. Muhammad tumbuh dewasa dibawah asuhan Abu Thalib dan harus belajar mengenai bisnis perdagangan dari pamannya. Ketika dewasa dan menyadari bahwa pamannya bukanlah orang berada serta memiliki keluarga besar yang harus diberi nafkah, Muhammad mulai berdagang sendiri di kota Makkah. Ia melakukan bisnis pada taraf kecil dengan cara membeli barang-barang dari satu pasar lalu menjualnya pada orang lain. Disamping itu, walaupun ia tidak memiliki uang sendiri untuk melakukan bisnis sendiri, tetapi ia banyak menerima modal dari janda-janda kaya dan anak yatim yang tidak sanggup menjalankan sendiri dana mereka. Dan menyabut baik seorang yang jujur untuk menjalankan bisnis dengan uang yang mereka miliki berdasarkan kerja sama.

Posisi ini, membuka tabir kebekuan dan terbentang peluang, kesempatan yang luas bagi Muhammad untuk memasuki dunia bisnis dengan cara menjalankan modal orang lain baik denga upa maupun berdasarkan persetujuan system bagi hasli sebagai mitra. Khadijah salah seorang dari banyak wanita kaya di Makkah yang menjalankan bisnisnya melalui agen-agen berdasarkan berbagai jenis kontrak. Muhammad sejak kecil terkenal rajin dan percaya diri, dan mendapatkan reputasi yang baik ketika dewasa. Sehingga dengan kondisi sedemikian itu ia membina dirinya

\footnotetext{
${ }^{9}$ Fazrul rahman, Op, Cit. h. 5
} 
menjadi seorang pedagang yang professional, yang memiliki reputasi dan integrsi yang luar biasa.

Nabi melakukan kunjungan dagang kepasar Habasyah, yang merupakan kota dagang di Tihamah. ${ }^{10}$ Ia juga berkunjing dagang ke Syiria, Jorasy, serta perlawanan ke Bahrain di bagian timur semenanjung Arab. Sofa, Musaqqhar, Hijar, dan Absinia menurut Geogrefi Arab Kuno . hal ini dilakukan oleh Muhammad sebab Abu Thalib memintah Nabi untuk menjalankan bisnis sendiri, dan Nabi juga tidak suka berlama-lama menjaddi tanggungan pamannya yang miskin.

Dalam dunia usaha transaksi kontan dan kredit sering terjadi, hal ini dapat kita liat pada kegiatan pembelian kredit yang dikaukan oleh Nabi, kredit unta, kuda, pohon kelapa, dan lainlain. Hal ini dapat dilihat dari deskripsi tempat-tempat perdagangan di Arabia pada masa itu yang dilukiskan oleh Muhammad Ibnu Habib Baghdadi sebanyak 13 buah sebagai berikut:

1. Pumatul janda adalah pasar ini ternak dan berposisi pada daerah ujung Utara Hijaz dekat perbatasan Syiria waktu itu. Pada pasar ini diadakan transaksi dagang setiap tahun pada awal bulan rabiul Awwal.

2. Mushaqqar adalah merupakan sebuah kota terkenal di Hijar (Bahrain) dan tempat transaksi dagang yang dilakukan setiap bulan Jumadil Awwal.

3. Suhar adalah sebuah kota di Oman, pecan dagang berlangsung pada tempat ini pada bulan rajab selama 5 hari.

4. Daba adalah daerah transaksi dagang yang merupakan pindahan dari Suhar pada ahir bulan Rajab. Dan darah ini merupakan slah satu dari dua kota Laut Oman. Pada tempat ini dikunjungi oleh saudagar-saudagar dari daerah Sind, Hind, Cina dan banyak Negara-negara timur yang datang.

5. Shihr (Maharam) adalah sebua kita yang terletak di sebalah pantai laiut Arabia, antara aden dan Oman. Kota ini terkenal denganparfumnya yang disebut Ambar. Pecan dagang pada tempat ini dilangsungkan sejak awal hingga pertengahan bulan Sya'ban.

6. Aden adalah merupakan pasar yang diselenggarakan mulai tanggal satu hingga sepuluh Ramadhan. Pada pasar ini banyak dikunjungi oleh orang-orang dari timu dan selatan (pasar ini terletak pada wilayah Yaman).

7. San'a adalah sebuah pasar terkenal dan dilaksanakan setiap tanggal sepuluh hingga ahir ramadhan, yang terletak di ibukota yaman.

${ }^{10}$ Abdul A'la Maududi, Tafheem AlQuran tt.Vol. VI. H. 475-476 
8. Rabiyah adalah nama sebuah kota di Hadramaut yang dikauniahkan dengan pasar yang ada pada kota ini dan dilaksanakan pada setiap tanggal lima belas Dzul qaeddah dengan waktu sebulan.

9. Ukaz adalah nama sebuah tempat di ujung Najd, pasar ini dilaksanakan bersama dengan pasar di hadramaut dengan keunggulan melebihi pasar lainnya dalam hal kemegahan, hubungan dagang, manifestasi puisi dan kesukuan. Pasar ini diselenggarakan setiap akhir bulan Zulqaeddah. Pasar ini dikunjungi berbagai suku diantaranya suku Quraisy, Hawazin, Ghatafan, Aslam, Ahabish, Adl, ad Dish, al Haya dan Mustaliq (Terdapat dekat Thaif).

10. Dul Majaz adalah pasar yang terletak antara Ukaz dan Makkah, pasar ini dilaksanakan setiap tanggal tujuh bulan Dzu'al Hijjah.

11. Dalam perkembangan daerah pasar Dzul Majaz pindah ke Mina dan berlangsung selama musim haji.

12. Nazat adalah daerah yang merupakan tempat pelaksanaan pasar dan termasuk wilayah Khaibar dengan kegiatan pasar dilaksanakan setiap tanggal sepuluh sampai akhir bulan Muharram.

13. Hujr adalah nama sebuah kota di yamamah. Pasar ini diadakan bersama dengan pasar Nazat setiap tanggal sepuluh sampai akhir bulan Muharram.

Seluruh pasar dagang ini diadakan di semenanjung Arabia, di Yaman orang-orang dari timur dan selatan berdatangan kesana secara berklelompok untuk menjalankan perdagangan. Sepintas berdatangan daftar ini, tampak bahwa pasar-pasar tersebut meliputi seluruh Arabia, dari Utara ke Timur, dari Timur ke Selatan ke Barat dan dari Barat ke Utara. Penulis pula menekankan bahwa pasar-pasar dagang ini bukanlah merupakan pasar local. Banyak orang yang berasal dari bagian-bagian yang jauh dari Negri itu dan dariluar negri ikut mendatanginya. 


\section{Kesimpulan}

Muhammad dibentuk oleh kondisi daerah makkah yang tandus menjadi seorang pedagang yang professional dimana daerah itu adalah jalur perdagangan Internasional. Kondisi ini dilatarbelakangi kejeniusan kake buyut Muhammad dalam membangun kontrak dagang keseluruh wilayah (Romawi dan Persi).

Sebagai seorang yang tidak punya ia membangun mitra perdagangan dengan jalan sebagai kerjasama (pemodal dan pengelola). Dalam kerjasama mendapatkan keuntungan dengan jalan system bagi hasil atau system pemberian upah. 


\section{DAFTAR PUSTAKA}

Abdul A'la Maududi, Tatheem Al-Qur'an, tt. Vol. VI

Fazlurrahman, Muhammad as A Trader, tyerjemah oleh Dewi Nurjulianti, Muhammad seorang Pedagang, Cet.I Jakarta; Yayasan Swarna Bhumy, 1995.

Fuad Hasan, Sirah Muhammad Rasulullah Suatu Penafsiran Baru, (Cet. V, Bandung; Mizan, 1996).

Hasan Ibrahim Hasan, diterjemahkan oleh Jahdan Human, Sejarah dan Kebudayaan Islam, (Cet. I Yogyakarta; Kota Kembang 1989.

Muhammad ibn Habib Baghdadi, Al Muhabbar, Da'irah al Mu'arif al Utsmanyiyyah, Hyderabad, Deccan, India, 1942.

Muhammad Husain Haekal, Sejarah Hidup Muhammad, (Cet.I, Jakrta; PT. Tintamas Indonesia, 1997. 